\title{
Performan Anak Babi Silangan Berdasarkan Paritas Induknya
}

\author{
N.Wahyuningsih, Y.B.P. Subagyo, Sunarto, S. Prastowo dan N. Widyas \\ Jurusan Peternakan, Fakultas Pertanian, Universitas Sebelas Maret Surakarta \\ Jl. Ir. Sutami 36A, Surakarta 57126 - Indonesia \\ Email: nur.wahyuningsih@gmail.com
}

\begin{abstract}
ABSTRAK
Penelitian ini bertujuan untuk mengetahui pengaruh paritas induk terhadap performan anak babi silangan. Penelitian dilakukan selama empat bulan di perusahaan babi CV. Adhi Farm, Kebakkramat, Karanganyar. Materi yang digunakan adalah babi pejantan berjumlah tiga ekor berbangsa Landrace, Duroc dan Hampshire. Babi betina berjumlah 21 ekor berbangsa Landrace dan anak babi dari hasil perkawinan serta data recording. Rancangan percobaan menggunakan. Data dianalisis berdasarkan Rancangan Tersarang (Nested Design) dan dilanjutkan dengan Uji Beda Nyata Terkecil (Least Significant Difference) untuk paritas yang tersarang pada pejantan dan Uji Jarak Berganda Duncan's (Duncan's Multiple Range Test) untuk paritas. Hasil penelitian menunjukkan bahwa paritas dan paritas yang tersarang pada pejantan memberikan pengaruh sangat nyata $(\mathrm{P}<0,01)$ terhadap bobot lahir dan littersize. Bobot lahir dan littersize yang dibandingkan dari tiap paritas maupun tiap paritas yang tersarang pada pejantan menunjukkan perbedaan nyata $(\mathrm{P}<0,05)$. Kesetimbangan bobot lahir dan littersize anak babi silangan terdapat pada paritas 1. Korelasi antara bobot lahir dengan littersize bernilai -0,17. Variasi bobot lahir dalam sekelahiran adalah 0,02 - 0,16. Kesimpulan penelitian ini adalah paritas induk berpengaruh terhadap performan bobot lahir dan littersize anak babi silangan.
\end{abstract}

Kata kunci : performan, anak babi, paritas induk

\section{(Performance of Hybrid Piglets Based on Sow Parity)}

\begin{abstract}
The aim of this study was to determine the effect of performance of the parent parity of hybrid piglets, and to know the parity that produces good performance of the hybrid piglets. This research was conducted for four months in the company of CV. Adhi Farm in Kebakkramat, Karanganyar. The material were three boars (Landrace, Duroc and Hampshire), 21 Landrace sows, piglets from the marriage, and the data from the company. The design of experiments was nested design. The variables that were observed or estimated included birth weight, littersize, the correlation of littersize to the birth weight, and birth weight variation in birth. The data showed the influence, then followed by Least Significant Difference Test (Least Significant Difference) for parity nested in males and Duncan's Multiple Range Test for parity. The results showed that parity and male parity nested exerted a highly significant $(P<0.01)$ for birth weight and littersize. Between birth weight and littersize were compared from each parity and each male parity nested were significantly different $(P<0.05)$. Balanced birth weight and hybrid piglets littersize were at parity 1 . The correlation between weight birth and littersize were -0,17. The variation in birth weight per littersize was 0,02 to 0,16. The conclusion of this study is the influence of the parity sow has effect on birth weight of piglet's performance of hybrids and littersize.
\end{abstract}

Keywords: performance, piglets, sow parity 


\section{PENDAHULUAN}

Ternak babi merupakan salah satu komoditi ternak penghasil protein hewani yang mempunyai peranan penting dalam hal pemenuhan konsumsi daging. Menurut Sution (2010), beberapa alasan mengapa ternak babi mempunyai arti penting dalam ekonomi di antaranya, karena babi dapat menghasilkan keuntungan yang relatif cepat dari modal yang dikeluarkan. Babi dapat beranak dua kali dalam setahun dan sekali beranak dapat menghasilkan anak yang banyak. Babi juga mudah beradaptasi dengan lingkungan. Sementara di sisi lain, pakan untuk babi mudah diperoleh karena tersedia di alam sehingga babi dapat dijadikan sebagai salah satu sumber pendapatan masyarakat/peternak.

Babi memiliki keunggulan daripada ternak lain seperti sifat produksi dan reproduksinya. Pardosi (2004) menyatakan beberapa sifat penting pada ternak babi adalah jumlah anak yang dilahirkan per induk per kelahiran, bobot lahir, jumlah anak lepas sapih, dan bobot sapih. Hal ini sangat dipengaruhi oleh perkawinan antar bangsa dan frekuensi beranak dari induk (parity) atau paritas. Paritas induk berhubungan dengan umur induk saat melahirkan anak, maupun jumlah anak yang dilahirkan. Jumlah anak yang dilahirkan (littersize) akan meningkat jika induk memiliki paritas tinggi. Hal ini sehubungan dengan kondisi fisiologis organ reproduksi induk yang berkembang sejalan dengan stadium kebuntingan (Partodihardjo, 1982).

Kapasitas induk dalam menampung jumlah fetus yang dikandung berbanding lurus dengan jumlah anak yang akan dilahirkan. Jumlah anak yang dilahirkan berpengaruh pada besar kecilnya bobot lahir anak babi yang dihasilkan. Fenton et al. (1970) menyatakan bahwa kapasitas induk dalam menampung fetus akan terbatas, sehingga littersize pun juga akan terbatas. Hal ini berhubungan dengan pendistribusian nutrisi dari induk yang merata pada fetus. Kemampuan fetus dalam mencerna nutrisi dari induk akan menyebabkan perbedaan bobot lahir fetus dalam sekelahiran. Selain itu, tinggi rendahnya bobot lahir anak babi dipengaruhi oleh banyak sedikitnya anak babi yang dilahirkan dalam sekelahiran. Jumlah anak babi yang banyak akan menurunkan bobot lahir, begitu juga sebaliknya. Jumlah anak babi per kelahiran dipengaruhi oleh beberapa faktor. Faktor tersebut adalah umur induk, bangsa, dan paritas (Gordon, 2008), genetik, manajemen, lama laktasi, penyakit, stres, dan fertilitas pejantan (Lawlor dan Lynch, 2007).

Paritas pertama pada induk akan menghasilkan anak babi yang lebih sedikit jika dibandingkan pada kelahiran berikutnya. Jumlah anak babi yang dilahirkan akan meningkat seiring dengan seringnya induk tersebut mengalami paritas, dan diharapkan anak babi dalam sekelahirannya menghasilkan performan yang lebih baik bila dibandingkan dengan induk yang hanya sekali mengalami paritas. Namun tiap kali paritas, induk akan menghasilkan variasi bobot lahir anak babi. Variasi bobot lahir anak babi sangat beragam karena dalam sekelahiran, induk dapat menghasilkan anak babi 6-12 ekor. Jumlah anak sekelahiran yang sedikit akan meningkatkan bobot lahir, begitu juga sebaliknya. Anak babi yang dilahirkan dalam jumlah yang banyak akan menurunkan bobot lahir (Gordon, 2008). Oleh karena itu, anak-anak babi tersebut dapat digunakan untuk mengetahui sejauh mana pengaruh paritas induk dalam menghasilkan performan yang baik bagi anak babi.

\section{MATERI DAN METODE}

Materi yang digunakan dalam penelitian adalah babi jantan, babi betina dan anak babi serta data yang diperoleh dari perusahaan CV. Adhi Farm. Pejantan yang digunakan berjumlah tiga ekor dan berasal dari bangsa yang berbeda yaitu : Landrace, Duroc dan Hampshire. Betina yang digunakan berjumlah 21 ekor berbangsa 
Landrace. Satu ekor pejantan mengawini tujuh ekor babi betina. Keturunan hasil dari perkawinan tersebut diamati performan bobot lahirnya.

Proses pengambilan data dilakukan dengan pencatatan data tetua yang diperoleh dengan melihat recording baik dari induk dan dari pejantan yang digunakan saat proses perkawinan. Recording dari induk berupa nama, bangsa, umur, paritas keberapa dan pejantan yang digunakan. Selain itu, diambil pula data dari recording pejantan berupa nama, bangsa, dan umur. Kemudian ditunggu sampai induk tersebut bunting dan beranak. Selanjutnya, saat induk melahirkan anak babi silangan, anak babi tersebut ditimbang segera atau dalam kurun waktu kurang dari 24 jam setelah dilakukan penanganan berupa pembersihan cairan amnion dan pemotongan plasenta. Pencatatan yang dilakukan meliputi bobot lahir dan littersize anak babi dalam sekelahiran.

\section{Analisis Statistik}

Semua data yang diperoleh dalam penelitian ini dianalisis menggunakan Rancangan Tersarang (Nested Design). Rancangan tersebut berfungsi untuk mengetahui adanya pengaruh paritas terhadap peubah yang diamati yaitu bobot lahir dan littersize. Model analisis: $Y_{i j k}=\mu+\alpha_{i}+\alpha(\beta)_{i j}+E_{\mathrm{ijk}}$ (Astuti, 1980).

Pengaruh lingkungan dalam penelitian ini dianggap tidak ada. Semua babi berada di bawah satu manajemen sehingga faktor lingkungan seperti cuaca, kondisi kandang, dan pakan semuanya seragam. Faktor yang diteliti adalah pengaruh dari tetua jantan $\left(\alpha_{i}\right)$ dan pengaruh dari betina $(\beta)$ dalam hal ini adalah paritasnya. Rancangan tersarang dipilih karena faktor-faktor yang diamati adalah pejantan dan betina (dalam hal ini paritas) yang tersarang dalam pejantan. Pejantan kawin dengan beberapa betina, sedangkan betina hanya bisa kawin dengan satu pejantan. Selanjutnya, faktor induk (baik jantan dan betina) akan dianalisis dengan anova. Apabila hasil analisis data menunjukkan adanya pengaruh nyata, maka dilanjutkan dengan Uji Beda Nyata Terkecil (BNT/Least Significant Difference) untuk paritas yang tersarang pada pejantan dan Uji Jarak Berganda Duncan's (Duncan's Multiple Range Test/DMRT) untuk paritas.

Kemudian untuk korelasi bobot lahir dengan littersize, dan variasi bobot lahir dalam sekelahiran dapat dilakukan dengan perhitungan tertentu. Menurut Hardjosubroto (1994), rumus untuk korelasi bobot lahir dengan littersize adalah

$$
r_{G}=\frac{\operatorname{cov}_{s}}{\sqrt{\left(\sigma_{s(x)}^{2}\right)\left(\sigma_{s(y)}^{2}\right)}}
$$

Keterangan :

$r_{G} \quad=$ korelasi genetik antara bobot lahir dengan littersize

$\operatorname{cov}_{s}=$ komponen peragam antar bobot lahir dengan littersize

$\sigma_{s}^{2}=$ komponen peragam bobot lahir dan atau littersize

Sedangkan untuk rumus variasi bobot lahir dalam sekelahiran menurut Steel dan Torrie (1995)

$$
\sigma^{2} x=\frac{\sum(x-\mu x)^{2}}{n-1}
$$

Keterangan :

$\sigma^{2} x=$ variasi bobot lahir dalam satu littersize yang sama

$n \quad=$ jumlah anak dalam satu induk yang sama

\section{HASIL DAN PEMBAHASAN}

\section{Bobot Lahir dan Littersize Berdasarkan Paritas}

\section{Bobot Lahir}

Rerata bobot lahir anak babi silangan berdasarkan paritas induknya disajikan dalam Tabel 1 dan 2. Paritas dan paritas yang tersarang pada pejantan dapat memberikan pengaruh sangat nyata $(\mathrm{P}<0,01)$ terhadap bobot lahir. Selain itu, antara bobot lahir yang dibandingkan dari tiap paritas dan 
tiap paritas yang tersarang pada pejantan menunjukkan perbedaan nyata $(\mathrm{P}<0,05)$. Menurut Sihombing (1997) rerata bobot lahir anak babi bervariasi antara 1,09 sampai $1,77 \mathrm{~kg}$. Sementara hasil penelitian diperoleh bahwa rerata bobot lahir anak babi silangan adalah 1,44 kg. Rerata bobot lahir anak babi yang baik terdapat pada paritas 1 , 2, 3, 7 dan 9 (Tabel 2).

Paritas kedua mempunyai bobot lahir anak babi silangan yang lebih besar bila dibandingkan dengan paritas pertama (Tabel 2). Hal tersebut disebabkan adanya banyak faktor yang mempengaruhi. Bobot lahir anak sangat bervariasi dan dipengaruhi beberapa faktor seperti genetik, pakan (Sihombing, 1997), jenis kelamin anak (Widodo dan Hakim, 1981), littersize dan paritas (Akdag et al., 2009). Bobot lahir lebih dipengaruhi oleh faktor keindukan (maternal effect). Faktor keindukan ada dua yaitu prenatal (di dalam uterus) dan postnatal (kehidupan anak babi setelah proses kelahiran). Penurunan bobot lahir di sini disebabkan oleh maternal effect pada saat prenatal. Menurut Widodo dan Hakim (1981), semua faktor yang memberikan dan menjaga pertumbuhan dari fetus dalam uterus dapat mempengaruhi bobot lahir anak babi. Selain itu, jumlah fetus yang dikandung oleh induk sangat berdampak pada masa kebuntingan. Jika jumlah fetus sedikit, maka perkembangan fetus di dalam uterus akan memakan waktu lama sehingga kebuntingan juga akan lama dan bobot badan anak babi akan membesar (Gordon, 2008). Jadi, setiap paritas induk mempunyai pengaruh yang berbeda pada besarnya bobot lahir anak babi silangan.

\section{Littersize}

Rerata littersize anak babi silangan berdasarkan paritas induknya disajikan dalam Tabel 1 dan 2. Paritas dan paritas yang tersarang pada pejantan dapat memberikan pengaruh yang sangat nyata $(\mathrm{P}<0,01)$ terhadap littersize. Selain itu, antara littersize yang dibandingkan dari tiap paritas dan tiap paritas yang tersarang pada pejantan menunjukkan perbedaan sangat nyata $(\mathrm{P}<0,01)$. Rerata littersize anak babi sekelahiran yang baik terdapat pada paritas 1, 6, dan 8 (Tabel 1).

Littersize pada paritas ketiga cenderung stabil dengan hasil 11 ekor anak per kelahiran (Tabel 1). Menurut Lawlor dan Lynch (2007), sejak kelahiran pertama, jumlah anak cenderung meningkat dan mencapai puncak pada kelahiran ketiga dan keempat, lalu stabil hingga kelahiran ketujuh dan selanjutnya menurun. Penyebabnya menurut Sihombing (1997) adalah ovulasi pada babi induk mengovulasikan lebih banyak rata-rata dua ovum daripada babi dara. Laju ovulasi akan meningkat terus hingga paritas ketujuh tetapi pada umumnya induk babi diafkir pada paritas kelima dan keenam. Hal ini dikarenakan daya reproduksi yang mulai menurun sehingga menghasilkan laju kebuntingan yang rendah. Selain itu, menurut Tomaszewska et al.(1991), semakin dewasa induk, semakin bertambah bobot hidupnya yang diikuti dengan kematangan fungsi organ reproduksi, sehingga meningkatkan daya tampung uterus dan memungkinkan perkembangan fetus secara maksimal.

Littersize merupakan efek dari hasil fertilitas induk dengan pejantan serta sistem manajemen kontrol yang dilakukan baik saat perkawinan maupun saat pemeliharaan. Littersize akan dipengaruhi oleh umur induk, bangsa, dan paritas (Gordon, 2008). Menurut French et al. (1979), littersize akan meningkat diikuti dengan umur, tetapi pada paritas tidak memberikan pengaruh yang berbeda pada littersize dalam umur yang sama. Hal tersebut juga menunjukkan hasil yang sama yaitu jika paritas meningkat, maka littersize tidak selalu diimbangi adanya peningkatan (Tabel 2).

\section{Kesetimbangan Bobot Lahir dengan Littersize Berdasarkan Paritas}

Rerata bobot lahir anak babi dan littersize yang baik terdapat pada paritas 1 , 2, 3, 7, 9 dan paritas 1, 6, 8 (Tabel 2). Jadi rerata yang baik berdasarkan kesetimbangan bobot lahir dan littersize anak babi silangan 
Tabel 1. Rerata bobot lahir dan littersize anak babi silangan berdasarkan paritas induk yang tersarang pada pejantan

\begin{tabular}{|c|c|c|c|c|c|}
\hline Paritas & $\begin{array}{l}\text { Umur Induk } \\
\text { (tahun) }\end{array}$ & Persilangan & $\begin{array}{l}\text { Rerata Bobot } \\
\text { Lahir (kg) }\end{array}$ & $\begin{array}{c}\text { Variasi Bobot Lahir dalam } \\
\text { sekelahiran }\end{array}$ & $\begin{array}{l}\text { Littersize } \\
\text { (ekor) }\end{array}$ \\
\hline 1 & 1 & $\mathrm{D} \times \mathrm{L}_{1}$ & $1,26^{\mathrm{x}}$ & $0,03 \pm 0,17$ & $12^{\mathrm{bc}}$ \\
\hline 1 & 1 & $\mathrm{H} \times \mathrm{L}_{8}$ & $1,73^{x}$ & $0,16 \pm 0,39$ & $13^{b}$ \\
\hline 1 & 1 & $\mathrm{H} \times \mathrm{L}_{9}$ & $1,58^{x}$ & $0,09 \pm 0,31$ & $12^{b}$ \\
\hline 2 & 1,5 & $\mathrm{H} \times \mathrm{L}_{10}$ & $1,60^{\mathrm{x}}$ & $0,06 \pm 0,25$ & $12^{\mathrm{bc}}$ \\
\hline 2 & 1,5 & $\mathrm{Lx} \mathrm{L} \mathrm{L}_{15}$ & $1,63^{x}$ & $0,04 \pm 0,19$ & $10^{\text {bcde }}$ \\
\hline 3 & 2 & $\mathrm{D} \times \mathrm{L}_{2}$ & $1,43^{x}$ & $0,03 \pm 0,18$ & $11^{\text {bcd }}$ \\
\hline 3 & 2 & $\mathrm{H} \times \mathrm{L}_{11}$ & $1,65^{\mathrm{x}}$ & $0,04 \pm 0,20$ & $11^{\mathrm{bcd}}$ \\
\hline 3 & 2 & $\mathrm{~L} x \mathrm{~L}_{16}$ & $1,45^{\mathrm{x}}$ & $0,03 \pm 0,18$ & $11^{\mathrm{bcd}}$ \\
\hline 4 & 2,5 & $\mathrm{D} \times \mathrm{L}_{3}$ & $1,26^{\mathrm{x}}$ & $0,10 \pm 0,31$ & $11^{\mathrm{bcd}}$ \\
\hline 5 & 3 & $\mathrm{H} \times \mathrm{L}_{12}$ & $1,15^{\mathrm{y}}$ & $0,10 \pm 0,31$ & $13^{b}$ \\
\hline 5 & 3 & $\mathrm{~L} x \mathrm{~L}_{17}$ & $1,67^{\mathrm{x}}$ & $0,12 \pm 0,34$ & $9^{\text {bcde }}$ \\
\hline 6 & 3 & $\mathrm{D} \times \mathrm{L}_{4}$ & $1,15^{\mathrm{y}}$ & $0,09 \pm 0,29$ & $13^{b}$ \\
\hline 7 & 3,5 & $\mathrm{D} \times \mathrm{L}_{5}$ & $1,83^{x}$ & $0,05 \pm 0,22$ & $10^{\text {bcde }}$ \\
\hline 7 & 3,5 & $\mathrm{H} \times \mathrm{L}_{13}$ & $1,18^{\mathrm{y}}$ & $0,08 \pm 0,28$ & $9^{\text {bcdef }}$ \\
\hline 7 & 3,5 & $\mathrm{Lx} \mathrm{L} \mathrm{L}_{18}$ & $1,31^{\mathrm{x}}$ & $0,07 \pm 0,26$ & $12^{\mathrm{bc}}$ \\
\hline 7 & 3,5 & $\mathrm{~L} \times \mathrm{L}_{19}$ & $1,65^{x}$ & $0,11 \pm 0,33$ & $11^{\mathrm{bc}}$ \\
\hline 8 & 4 & $\mathrm{D} \times \mathrm{L}_{6}$ & $1,30^{\mathrm{x}}$ & $0,07 \pm 0,26$ & $11^{\text {bcd }}$ \\
\hline 8 & 4 & $\mathrm{H} \times \mathrm{L}_{14}$ & $1,26^{\mathrm{x}}$ & $0,07 \pm 0,26$ & $14^{\mathrm{a}}$ \\
\hline 8 & 4 & $\mathrm{~L} \times \mathrm{L}_{20}$ & $1,44^{\mathrm{x}}$ & $0,07 \pm 0,26$ & $14^{\mathrm{a}}$ \\
\hline 9 & 4,5 & $\mathrm{~L} \times \mathrm{L}_{21}$ & $1,51^{\mathrm{x}}$ & $0,04 \pm 0,20$ & $11^{\text {bcd }}$ \\
\hline 10 & 5 & $\mathrm{D} \times \mathrm{L}_{7}$ & $1,24^{\mathrm{x}}$ & $0,02 \pm 0,14$ & $10^{\text {bcde }}$ \\
\hline \multicolumn{2}{|r|}{ Total } & 21 & 1,44 & - & 11,60 \\
\hline
\end{tabular}

Keterangan : $\mathrm{D}=$ Duroc, $\mathrm{L}=$ Landrace, $\mathrm{H}=$ Hampshire .

a,b,c,d,e,f,x,y Superskrip yang berbeda pada kolom yang sama menunjukkan adanya perbedaan nyata $(\mathrm{P}<0,05)$

Tabel 2. Rerata bobot lahir dan littersize anak babi silangan berdasarkan paritas induknya

\begin{tabular}{|c|c|c|c|c|c|}
\hline Paritas & $\begin{array}{l}\text { Umur Induk } \\
\text { (tahun) }\end{array}$ & $\begin{array}{l}\text { Jumlah Induk } \\
\text { (ekor) }\end{array}$ & $\begin{array}{c}\text { Jumlah Anak } \\
\text { Babi (ekor) }\end{array}$ & $\begin{array}{c}\text { Rerata Bobot } \\
\text { Lahir (kg) }\end{array}$ & $\begin{array}{l}\text { Rerata Littersize } \\
\text { (ekor) }\end{array}$ \\
\hline 1 & 1 & 3 & 37 & $1,53^{\mathrm{vw}}$ & $12,35^{\mathrm{c}}$ \\
\hline 2 & 1,5 & 2 & 22 & $1,61^{\mathrm{v}}$ & $11,09^{\mathrm{e}}$ \\
\hline 3 & 2 & 3 & 33 & $1,51^{\mathrm{vw}}$ & $11,00^{\mathrm{e}}$ \\
\hline 4 & 2,5 & 1 & 11 & $1,26^{x y}$ & $11,00^{\mathrm{e}}$ \\
\hline 5 & 3 & 2 & 22 & $1,36^{\mathrm{wx}}$ & $11,36^{d}$ \\
\hline 6 & 3 & 1 & 13 & $1,15^{\mathrm{y}}$ & $13,00^{b}$ \\
\hline 7 & 3,5 & 4 & 42 & $1,50^{\mathrm{vw}}$ & $10,62^{f}$ \\
\hline 8 & 4 & 3 & 39 & $1,33^{\text {wxy }}$ & $13,15^{\text {a }}$ \\
\hline 9 & 4,5 & 1 & 11 & $1,51^{\mathrm{vw}}$ & $11,00^{\mathrm{e}}$ \\
\hline 10 & 5 & 1 & 10 & $1,24^{x y}$ & $10,00^{\mathrm{g}}$ \\
\hline \multicolumn{2}{|c|}{ Total } & 21 & 240 & 1,46 & 11,60 \\
\hline
\end{tabular}

a,b,c,d,e,f,g,v,w,x,y Superskrip yang berbeda pada kolom yang sama menunjukkan adanya perbedaan nyata $(\mathrm{P}<0,05)$ 
terdapat pada paritas 1 . Hal ini menunjukkan bahwa pada paritas 1 atau babi dara dapat memberikan hasil yang lebih baik pada bobot lahir maupun littersize jika dibandingkan dengan paritas seterusnya atau pada babi induk. Hal ini kemungkinan disebabkan oleh beberapa faktor selain dari faktor cuaca, kondisi kandang, pakan dan perlakuan semuanya seragam. Keberhasilan perkawinan dipengaruhi oleh deteksi berahi yang tepat. Deteksi berahi dapat ditingkatkan dengan cara melihat tingkah laku induk ketika terjadi kontak langsung dengan pejantan.

Perkawinan pada babi betina (baik itu babi dara maupun babi induk) yang dilakukan berdasarkan puncak berahi pada babi dara, dapat menimbulkan perbedaan pada performan anak yang dilahirkan oleh babi dara maupun babi induk. Perkawinan yang dilakukan tidak tepat pada waktunya, seperti pengawinan terlalu dini atau saat berahi yang terlewatkan dapat menyebabkan kegagalan pembuahan (fertilisasi) sehingga persentase kebuntingan rendah. Menurut Sihombing (1997), jika perkawinan dilakukan terlalu awal, sperma tiba di tuba fallopii terlalu awal dan mungkin mati sebelum ada telur yang lepas. Bila dikawinkan terlalu lambat, telur terlalu masak (lebih dari enam jam) dan akan berakibat lebih dari satu sperma masuk ke dalam satu telur untuk membuahi (polyspermy). Menurut Partodihardjo (1982) bahwa jika terjadi polispermia maka fertilisasi bisa dianggap gagal karena dapat menghasilkan makhluk baru dengan jumlah kromosom lebih dari normalnya. Kromosom tersebut bersifat letal dan makhluk tersebut akan mati sebelum implantasi terjadi.

Selain itu, kematian embrio dapat disebabkan oleh tidak setimbangnya jumlah ovum yang dikeluarkan dari ovarium dengan ovum yang dapat dibuahi. Banyaknya ovum yang diovulasikan pada babi induk lebih tinggi daripada babi dara sehingga babi induk cenderung lebih banyak mengalami kematian embrio. Kematian embrio dini dan ketidakseimbangan lingkungan di dalam uterus induk dapat menyebabkan berkurangnya jumlah anak yang dilahirkan. Tomaszewska et al. (1991) menyatakan bahwa kematian embrio dini disebabkan oleh kematian embrio sebelum implantasi (perlekatan) pada dinding uterus, sebagian besar disebabkan tidak normalnya kromosom yang berhubungan dengan pembuahan dan pembelahan awal dari sel yang tidak dapat dihindari atau dicegah. Sementara di sisi lain, Toelihere (1993) menyatakan bahwa kematian prenatal atau kematian embrio dini kemungkinan akan naik seiring dengan umur dan paritas. Penyebabnya ialah angka ovulasi yang meninggi tetapi tidak diikuti dengan perbaikan jumlah litter, serta kondisi lingkungan yang kurang baik di dalam uterus. Kondisi lingkungan yang kurang baik di dalam uterus disebabkan ada tiga yaitu, penyakit, stres dan hormonal (Hardjopranjoto, 1995). Pertama, penyakit pada induk yang menimbulkan peningkatan suhu tubuh dan demam dapat menimbulkan kematian embrio. Kedua, faktor stres panas pada uterus disebabkan suhu kandang yang tinggi. Ketiga, faktor hormonal khususnya ketidakseimbangan hormon estrogen dan progesteron.

Dasar dari manajemen paritas yang baik ialah bersatunya kebaikan dari faktor genetik dan lingkungan. Thornton (2011) menyatakan bahwa keputusan dalam kunci untuk memanajemen kontrol pada paritas, tertumpu pada beberapa informasi dasar tentang keadaan spesifik dari produktivitas. Produktivitas dari paritas dapat dicapai jika genotip dan sistem manajemen saling beriringan agar dapat memaksimalkan keuntungan dari sebuah "farm" dan distribusi paritas.

\section{Korelasi Bobot Lahir dengan Littersize}

Hasil analisis korelasi antara bobot lahir dengan littersize anak babi silangan bernilai -0,17. Nilai tersebut menunjukkan tingkat keeratan yang rendah dari bobot lahir 


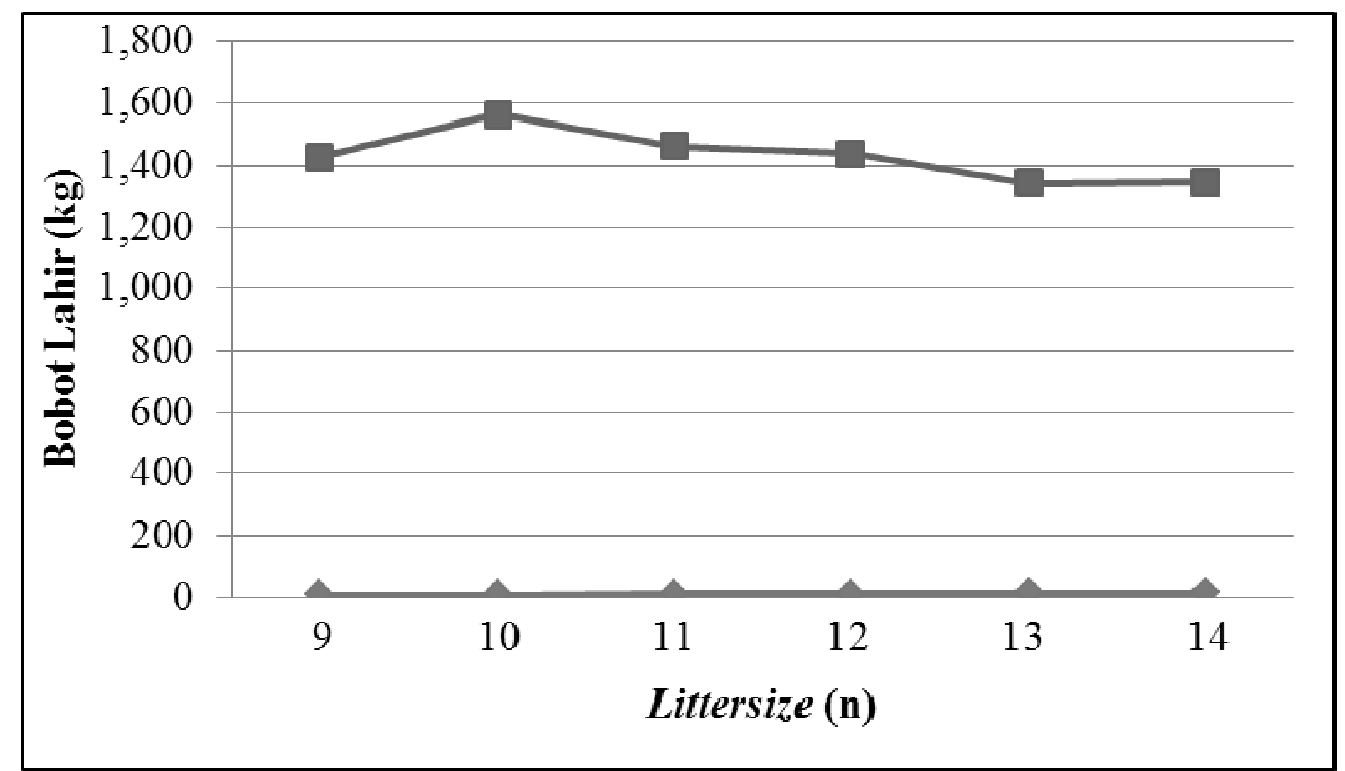

Gambar 1. Diagram garis hubungan bobot lahir dengan littersize

dengan littersize. Nilai korelasi rendah (nilai $\pm 0,1$ ) berarti jika dilakukan seleksi terhadap littersize maka akan memberikan respon peningkatan yang lemah terhadap bobot lahir. Menurut Akdag et al. (2009), paritas tidak berpengaruh terhadap bobot lahir anak babi, tetapi littersize memberikan pengaruh, karena hubungan antara bobot lahir anak babi dengan littersize menunjukkan korelasi yang negatif. Gambar 1 menunjukkan bahwa semakin banyak jumlah anak sekelahiran (littersize), maka bobot lahir akan semakin rendah, begitu juga sebaliknya. Menurut Warwick et al. (1984), korelasi genetik bersifat negatif akan membatasi kemajuan yang dapat dicapai untuk kedua sifat itu secara bersamaan. Jadi, persentase hubungan antara littersize dan bobot lahir pada hasil penelitian sebesar 16,6\% dipengaruhi oleh faktor genetik dan 83,4\% dipengaruhi lingkungan.

\section{Variasi Bobot Lahir dalam Sekelahiran}

Variasi bobot lahir dalam jumlah anak babi sekelahiran disajikan dalam Tabel 1, yaitu bervariasi antara 0,02 - 0,16 yang berarti tingkat variasi rendah. Semakin rendah nilai variasi dari bobot lahir dalam sekelahiran menunjukkan adanya banyak keseragaman dari bobot lahir dalam sekelahiran, begitu juga sebaliknya. Tingginya variasi dari bobot lahir dalam sekelahiran menunjukkan rendahnya keseragaman dari bobot lahir.

Milligan et al. (2002), menyatakan bahwa efek dari paritas memberikan pengaruh signifikan serta indikasi tingginya variasi dari rata-rata kelangsungan kehidupan anak babi pada paritas pertama atau paritas berikutnya. Hal ini dapat dilihat dari tingginya variasi seperti bobot lahir menghubungkan pada bobot sapih, tetapi tidak berpengaruh terhadap rerata bobot sapih. Pengaruh maternal effect pada masa postnatal (kehidupan anak babi setelah proses kelahiran) dan adanya faktor mortalitas diyakini sebagai faktor yang memberikan dampak pada kelangsungan anak babi dari bobot lahir sampai sapih (Legates, 1972).

\section{KESIMPULAN}

Paritas induk berpengaruh terhadap performan bobot lahir dan littersize anak babi silangan. Korelasi antara bobot lahir dengan littersize bernilai $-0,17$ (negatif) 
artinya bahwa tidak adanya hubungan (atau bersifat berkebalikan) dari keduanya. Semakin banyak littersize, maka bobot lahir akan semakin rendah, begitu juga sebaliknya. Selain itu, variasi bobot lahir dalam jumlah anak babi sekelahiran bervariasi yaitu 0,02 - 0,16. Semakin rendah nilai variasi dari bobot lahir dalam sekelahiran menunjukkan adanya banyak keseragaman dari bobot lahir dalam sekelahiran, begitu juga sebaliknya.

\section{UCAPAN TERIMA KASIH}

Terima kasih kepada CV. Adhi Farm yang telah memberikan fasilitas dan tempat dalam pelaksanaan penelitian ini.

\section{DAFTAR PUSTAKA}

Akdag, F., S. Arslan., and H. Demir. 2009. The Effect of Parity and Litter Size on Birth Weight and the Effect of Birth Weight Variations on Weaning Weight and PreWeaning Survival in Piglet. Journal of Animal and Veterinery Advances. 8 (11): 2133-2138.

Astuti, M. 1980. Rancangan Percobaan dan Analisa Statistik. Bagian Pemuliaan Ternak. Fakultas Peternakan Universitas Gadjah Mada. Yogyakarta.

Fenton, F.R., F.W. Bazer., O.W. Robinson and L.C. Ulberg. 1970. Effect of Quantity of Uterus on Uterine Capacity in Gilts. Journal of Animal Science. 31 : 104-106.

French, L.R., J.J. Rutledge, and N.L. First. 1979. Effect of Age and Parity on Litter Size in Pigs. Journal of Reproduction and Fertility. 57 : 59-60.

Gordon, I. 2008. Controlled Reproduction in Pigs. CAB International, Washington DC.

Hardjopranjoto, S. 1995. Ilmu Kemajiran pada Ternak. Airlangga University Press. Surabaya.

Hardjosubroto, W. 1994. Aplikasi Pemuliabiakan Ternak di Lapangan. Grasindo. Jakarta.
Lawlor, P.G., and P.B. Lynch. 2007. A Review of Factors Influencing Litter Size in Irish Sows. Irish Veterinary Journal. 60 (6) : 359366.

Legates, J.E. 1972. The Role of Maternal Effects in Animal Breeding : IV, Maternal Effects in Laboratory Species. Journal of Animal Science. 35 (6) : 1294-1302.

Milligan, B.N., D. Fraser., and D.L. Kramer. 2002. Within-Litter Birth Weight Variation in the Domestic Pig and Its Relation to PreWeaning Survival, Weight Gain, and Variation in Weaning Weights. Livestock Production Science. 76 : 181-191.

Pardosi, U. 2004. Pengaruh Perkawinan antara Tiga Bangsa Babi Terhadap Prestasi Anak dari Lahir sampai dengan Sapih di PT. Mabarindo Sumbul Multifarm. Tesis. Fakultas Peternakan Universitas Diponegoro. Semarang.

Partodihardjo, S. 1982. Ilmu Reproduksi Hewan. Mutiara. Jakarta.

Sihombing, D.T.H. 1997. Ilmu Ternak Babi. Gadjah Mada University Press. Yogyakarta.

Steel, R.G.D., dan J.H. Torrie. 1995. Prinsip dan Prosedur Statistika Suatu Pendekatan Biometrik. Edisi Kedua. PT Gramedia Pustaka Utama. Jakarta.

Sution. 2010. Beternak Babi. Balai Pengkajian Teknologi Pertanian. Kalimantan Barat.

Thornton, K. 2011. Gilt Development, Management and Parity Control. www.gov.mb.ca/agriculture/.../bab15s02.pd f. 22 Desember 2011.

Toelihere, M.R. 1993. Inseminasi Buatan pada Ternak. Angkasa, Bandung.

Tomaszewska, M.W., I.K. Sutama., I.G. Putu., dan T.D. Chaniago. 1991. Reproduksi, Tingkah Laku, dan Produksi Ternak di Indonesia. PT Gramedia Pustaka Utama. Jakarta.

Warwick, E.J., J.M. Astuti., dan W. Hardjosubroto. 1984. Pemuliaan Ternak. Gadjah Mada University Press. Yogyakarta.

Widodo, W. dan L. Hakim. 1981. Pemuliaan Ternak. Universitas Brawijaya. Malang. 